\title{
BEYOND THE MARGINS: \\ HUMAN RIGHTS VIOLATIONS AGAINST UNDOCUMENTED \\ PERSONS, HOMOSEXUALS, AND WOMEN \\ IN INTER-AMERICAN NARRATIVE
}

\author{
Sebastian Imoberdorf \\ University of Fribourg, Switzerland
}

\begin{abstract}
This study is greatly based on article 7 of the "Universal Declaration of Human Rights" that states: "All are equal before the law and are entitled without any discrimination to equal protection of the law." Latin America is viewed as a place where injustices and atrocities tend to be the order of the day: violent processes of conquest and colonization, military dictatorships, drug trafficking, kidnappings, the increase in crime and insecurity, etc. Such violations have generated frequent waves of emigration (often irregular) to the United States where they seek protection and freedom but, too often, they find neither, thus producing a vicious cycle in the inter-American literature of US Latino authors. The focus is to examine three distinct groups: immigrants, homosexuals and women.
\end{abstract}

Keywords: Human Rights Violations, 20th and 21st Century Inter-American Literature, Latinos in the US, Marginalized Groups.

TRASPASANDO LOS MÁRGENES:

VIOLACIONES DE LOS DERECHOS HUMANOS EN PERSONAS INDOCUMENTADAS, HOMOSEXUALES Y MUJERES EN LA NARRATIVA INTER-AMERICANA

\section{Resumen}

Este estudio se basa en gran parte en el artículo 7 de la "Declaración Universal de los Derechos Humanos", que dice: "Todos son iguales ante la ley y tienen, sin distinción, derecho a igual protección de la ley." Latinoamérica es vista como ejemplo donde injusticias y atrocidades han estado siempre a la orden del día: violentos procesos de conquista y colonización, las varias dictaduras militares, el narcotráfico, los secuestros, el aumento de la delincuencia y la inseguridad, etc. Tales violaciones han generado frecuentes olas de emigración (a menudo irregulares) hacia Estados Unidos, donde intentan encontrar protección y libertades, pero con frecuencia tampoco las encuentran, produciéndose así un círculo vicioso en la literatura interamericana de autores hispano-estadounidenses. El enfoque consistirá en examinar tres grupos distintos: los inmigrantes, los homosexuales y las mujeres.

Palabras clave: violaciones de los Derechos Humanos, narrativa interamericana de los siglos Xx y xxI, latinos en EE. UU., grupos marginados.

DOI: https://doi.org/10.25145/j.recaesin.2020.81.07

Revista Canaria de Estudios Ingleses, 81; November 2020, pp. 97-112; ISSN: e-2530-8335 
Por un lado, se podría decir que una de las razones de ser de un Estado democrático es la protección de los derechos humanos de los ciudadanos. Por el otro, debemos ser capaces de defender los derechos humanos de quienes no son ciudadanos. Si el Estado no puede proveer tal defensa, ¿qué hacemos? Es una cuestión de los derechos de quienes no pertenecen a ningún Estado y están implicados en acciones de guerra, pero también es cuestión de los indocumentados cuyos derechos humanos también deben ser protegidos. Si sólo consideramos como merecedoras de derechos a aquellas vidas que representan al Estado-nación, estamos definiendo tácitamente al ser humano en relación con su pertenencia a un Estado.

Judith Butler ("La lucha debe ser por una vida vivible")

\section{INTRODUCTION}

The Universal Declaration of Human Rights (1948) and its American equivalent, the American Declaration of the Rights and Duties of Man (1948), have existed for more than seventy years now. Although this may sound good in theory and seems sufficient to guarantee the defense of human rights in the world, the reality is often very different. Human rights violations in the Americas do not represent isolated or sporadic cases: on the contrary, they are the order of the day, so it is pertinent to ask the question why, despite the legal tools, we continue to witness such violations? The answer to this question is not unequivocal. Some specialists speak of the seniority of governments and the incompatibility between the universality of rights and the cultural particularities of different countries; others even reproach corrupt behavior of the various institutions responsible for overseeing by its not always strict compliance (Reyes-Zaga 121-122). Be that as it may, the problem remains.

It is noteworthy that this issue is also reflected in current inter-American narratives. Furthermore, literature not only plays an important role in denouncing human rights violations, but also in raising the awareness of the reader and transforming them into a social entity capable of actively participating and politically influencing the creation of a more equitable society. In other words, social participation is understood as that process in which people are consciously involved in the public sphere to generate positive change on issues that matter to them, as confirmed in Sidney Tarrow's El poder en movimiento (17-19).

This study tries to show different forms of human rights violations presented in US Latino narratives, focusing on three groups, often marginalized, within the larger community of Hispanics migrated to the US: undocumented persons, homosexuals, and women. In this essay, we concentrate on the analysis of three exemplary works of each group, which will be introduced with a short legal section: El corrido de Dante by Eduardo González Viaña, Antes que anochezca by Reinaldo Arenas, and El sueño de América by Esmeralda Santiago'.

${ }^{1}$ Since El corrido de Dante and Antes que anochezca were first written in Spanish, we will use and quote the original versions in this study. In order to be consistent, we will also use the Spanish version for El sueño de América (auto-translation by the novelist). 


\section{I. THE HUMAN RIGHTS OF UNDOCUMENTED MIGRANTS AND THEIR VIOLATIONS}

In the first subchapter we look at the rights of undocumented migrants and the violations they suffer. In accordance with the Universal Declaration of Human Rights, the American Declaration of the Rights and Duties of Man proclaims both the "Right to the inviolability and transmission of correspondence" (14) as well as the "Right to nationality" which provides for the following: "Every person has the right to the nationality to which he is entitled by law and to change it, if he so wishes, for the nationality of any other country that is willing to grant it to him" (4). It is precisely in this additional clause where the problem resides, given that not all States are willing to grant nationality to persons who, without the proper requirements, remain in their territory and who, therefore, are left in an irregular situation and without protection of their rights.

In the selected novels we will focus on the abuses of human rights during the different stages of migration, taking into account both the violations before emigrating (i.e. in the country of origin) and during the different phases that constitute the migration process, which are: the departure from the place of origin, the passage and often stay at the border; the crossing of the border; and finally the stay in the country of destination (Reyes-Zaga 126). A further stage, which does not occur in the works examined, would be the return to the home country, which entails specific problems and human rights violations (cf. Imoberdorf).

\section{II. EL CORRIDO DE DANTE BY EDUARDO GONZÁLEZ VIAÑA}

El corrido de Dante by Eduardo González Viaña can be considered one of the canonical works that deal with irregular ${ }^{2}$ Mexican migration to the United States. For the protagonist, Dante Celestino, the departure from the place of origin turns out to be motivated by economic reasons, when he recognizes that he can't get a job in Sahuayo, Michoacán, or Mexico in general and then decides to go to the United States to find his fortune there (González Viaña 61). We could say that this decision transforms Dante into the archetype of the (il)legal Mexican migrant who tries to find work, better possibilities and the protection of human rights in the North like many others of his compatriots.

For the irregular passing and crossing of the border, as the second stage of the migration process, there are several possibilities that may imply, each of them, a high risk of infringement of the migrant's human rights: the passage through the Río Bravo, the crossing of the desert, the access through the border fences, the hidden

\footnotetext{
2 In our study we prefer the terms "irregular" or "undocumented", which are more neutral than the pejorative designation "illegal".
} 
journey by car or train, the transfer with or without the help of a coyote, etc. The risk of human rights violations is yet increased by the new, tightened immigration policy of Donald Trump which promises to reduce irregular migration and makes it more difficult for people to immigrate to the US. As a consequence, migrants seek even more hidden and dangerous paths to reach their destination and so become particularly vulnerable.

In Dante's case, we learn that on his first entry into the United States he had chosen to cross the desert with two other migrants. The dimension of the danger of this type of border crossing becomes apparent to the reader when the characters discover three dead bodies (or at least see a Fata Morgana of three cadavers) and when Dante and his two companions are stopped by immigration agents who interrogate them before sending them back to Mexico (González Viaña 47-50).

But even Dante's wife Beatriz's passage does not take place without problems nor under better circumstances. There are several attempts to cross the border and all are made with the help of coyotes. At first, she intends to enter the United States by crossing the river and succeeds in doing so. But when she reaches the other side, she is immediately detained by the US Immigration Service and deported. A second attempt is even worse than the first: Beatriz approaches a gang of criminal coyotes whose only objective is to take advantage of the desperate situation of migrants. In addition, the reader learns that she narrowly escapes from attempted sexual abuse and this illustrates yet another danger that migrant women face. Javier Manzano Franco, for example, claims in his essay "El corrido de Dante de Eduardo González Viaña y la irrupción de lo mítico en la novela de la inmigración” that Beatriz’s solitary journey reflects the considerably worse conditions in which female migration to the United States takes place, frequently as victims not only of economic, but also of sexual extortion (44). This episode also shows the trade mechanism behind illegal human trafficking in which the coyotes act as businessmen and the migrants are often simply seen as a commodity. Although some States are already paying attention to the smuggling of migrants (if we think, for example, of the 2006 Protocol against the Smuggling of Migrants by Land, Sea and Air), the problem, and the human rights violations it entails, continue to exist. Nonetheless, Beatriz turns to the same family with whose help Dante was able to enter the United States, the Facundo family which has contacts throughout the US-Mexico border, and eventually manages to cross through a tunnel and finally meet her husband.

Once the migrants enter the United States, the next and, in the case of $E l$ corrido de Dante, the last phase of the immigration process begins. For some this stage is not as problematic, but for a large majority it implies major difficulties and conflicts such as, among other things, culture shock, absence of documents and, consequently, lack of work. This idea is supported by Audrey García in her article "Mexican Immigration and Popular Culture in El corrido de Dante by Eduardo González Viana" where she states: "For illegal Mexican immigrants the American dream is not to have material richness and freedom. Their only dream is to have a visa that enables them to work legally in the United States" (234). And that's exactly the case of Dante who's waiting 25 years for his green card. 
Another related problem is the often poor labor conditions for migrants without documents. In section VIII, "Rights of undocumented migrant workers", of the Advisory Opinion OC-18/03, the Inter-American Court of Human Rights declares that as soon as undocumented migrants are hired, they immediately become holders of the labor rights to which they are entitled and therefore must not be discriminated against because of their irregular situation. This issue is of major importance because one of the main problems that arise in the context of immigration is that migrant laborers, compared to other workers, are employed under unfavorable conditions without their work permits (106). Thus, in El corrido de Dante several rights are violated at the same time, such as that of Article 23 of the Universal Declaration of Human Rights, which demands, without discrimination, "equal pay for equal work" (6) or that of Article XIV of the American Declaration of the Rights and Duties of Man which declares: "Every person has the right to work, under proper conditions, and to follow his vocation freely, insofar as existing conditions of employment permit" (15).

We realize the human rights violations in the field of labor when we learn that Dante does not receive nearly the same salary as regular workers and that he must work more to support his family. The narrator of El corrido adds that everything Dante could spend was the product of many years on minimum wage which was the most a man without a green card was paid (González Viaña 17).

However, labor rights violations are by no means the only ones that Dante and his family have to face. A key episode in the novel, in which González Viaña demonstrates his great ironic finesse in revealing the discrepancy between the feigned intercultural policy of the United States and the rather discriminatory reality, is when Dante reports his daughter's disappearance to the police and an indelicate interpreter:

Al final, [la intérprete] le leyó la declaración de igualdad de oportunidades según la cual todos son iguales ante la ley y no se hace ningún tipo de discriminación por el origen, las convicciones ni la raza de las personas.

- A continuación, se pregunta aquí cuál es la raza de tu hija. ¿Puedes decir cuál es la raza de tu hija?

Dante se quedó callado un instante asombrado por el contrasentido, pero la señora no lo dejó responder.

- De color. Voy a poner aquí "de color" porque todos los hispanos son de color. $(36-37)$

This fragment is full of contradictions and the interpreter, who can be considered the stereotype of an archetypal conservative American woman, ignores with her retrograde and racist behavior several of the basic human rights. This episode of the incompetent translator at the police station in which Dante denounces Emmita's disappearance is inseparable from the one in which she, despite possessing American nationality and speaking perfect English, is sent to a class supporting ethnic minorities -where her training is spoiled- by her teachers, who, rooted in clearly racist prejudices, identify the Hispanic with the mestizo and cannot explain the white skin and light eyes of the girl, as Javier Manzano Franco (46) and Fredrik Olsson (67) consent in their respective essays. 
As an intermediate conclusion, it can be said that the migration process of undocumented migrants is a particularly vulnerable one, as can be seen in the analyzed novel El corrido de Dante. Various dangers already lurk on their way to the United States. Some of them opt for the risky crossing on the freight train "La Bestia" or "The Beast", where they are constantly exposed to the risk of falling off and being killed. Others cross the desert of the border zone, where the possibility of dying of thirst or being struck down by the sun is very high, as shown by Dante's encounter with the carcasses. Finally, there is the great danger of organized crime coyotes can be an integral part of this- that targets migrants with not only economic but also sexual exploitation, especially women. Besides, undocumented migrants in the US may face many problems, such as inhumane and exploitative working conditions or unequal and racist treatment, as evinced with Dante and his family.

\section{I. THE HUMAN RIGHTS OF HOMOSEXUALS AND THEIR VIOLATIONS}

No less complicated can be the situation for homosexual migrants. As far as their human rights are concerned, both the Universal Declaration of Human Rights and the American Declaration of the Rights and Duties of Man remain quite general, as shown in Article 2 of the former: "Everyone is entitled to all the rights and freedoms set forth in this Declaration, without distinction of any kind, such as race, color, sex, language, religion, political or other opinion, national or social origin, property, birth or other status." (2) Obviously, homosexuals or other member of the LGBTQ community (Lesbian, Gay, Bisexual, Transgender, Queer) also fall under this definition, but they are not explicitly mentioned. It is precisely this fact that can lead to false or even non-applications, particularly in countries where homosexuality is considered unnatural, sinful or even illegal and punishable as was the case in Cuba between the 1960s and 1980s. It is worth adding that at that time (and until 2009) Cuba was suspended by the Organization of American States (OAS) and therefore it lacked the control of that organization and thus also any form of protection. As a result, several human rights violations occurred and even laws were passed that contradicted the same human rights, as seen in the following sequence from the documentary Conducta impropia by Néstor Almendros and Orlando Jiménez Leal in which Reinaldo Arenas was interviewed:

Cuando Fidel Castro habla, incluso cuando pronuncia o publica, aquellas leyes que condenan a los mismos homosexuales o a cualquier ser humano, estos seres humanos tienen que ir a la Plaza de la Revolución y aplaudir aquellas leyes. $\mathrm{O}$ sea, resulta increíble que aquellas leyes por las cuales vamos a ir a los campos de trabajos forzados o a la cárcel, nosotros tenemos que aprobarlas y aplaudirlas. Todo ser humano tiene que hacer esta simulación porque uno depende del Estado. El Estado es que le da a uno trabajo, el Estado es que nos puede meter en la cárcel o que nos puede dar la posibilidad que uno puede, por ejemplo, estudiar en una universidad o que puede que uno pueda mejorar su empleo. Es decir que todo este 
tipo de leyes delirantes llevan a la persona a un estado paranoico ... (Conducta impropia 00:45:55-00:46:40)

It is not until 2013, quite recently, that the Inter-American Convention against All Forms of Discrimination and Intolerance was created, which in Article 1 does specify "sexual orientation" (3) as an independent factor. But it should be added that not all States of the OAS have yet signed the new treaty: among others, Cuba's approval is still missing.

\section{II. ANTES QUE ANOCHEZCA BY REINALDO ARENAS}

The fact that Cuba was suspended by the OAS from 1962 to 2009 does not mean that during that time there were no violations to human rights. On the contrary, the lack of control and defense led to a high number of such violations. Reinaldo Arena's novelized autobiography ${ }^{3}$ Antes que anochezca represents, in various ways, an eloquent testimony of such infractions. Unlike El corrido de Dante, the description of the migratory process does not occupy so much space as does residence in the country of origin itself, which is presented as a panopticon with no exit.

A first violation of a fundamental right is already evident in the nonapplication of Article II of the American Declaration of the Rights and Duties of Man (which is a combination of Articles 2 and 7 of the UDHR). There the "Right of equality before law" is proclaimed according to which: "All persons are equal before the law and have the rights and duties established in this Declaration, without distinction as to race, sex, language, creed or any other factor" (2). But the reality turns out to be different. In Cuba at that time, being homosexual also meant, in addition to a condition of inferiority, a state of high risk, as the following quote from Arenas in Antes que anochezca illustrates:

[Y]o padecía todos los prejuicios típicos de una sociedad machista, exaltados por la Revolución; en aquella escuela desbordada de una virilidad militante no parecía haber espacio para el homosexualismo que, ya desde entonces, era severamente castigado con la expulsión y hasta con el encarcelamiento. Sin embargo, entre aquellos jóvenes se practicó de todos modos el homosexualismo, aunque de una manera muy velada. [...]

"Pájaro, eso es lo que tú eres", volvía a escuchar la voz de mi compañero de estudios cuando estaba en la escuela secundaria y comprendía que ser "pájaro» en Cuba era una de las calamidades más grandes que le podía ocurrir a un ser humano. (Arenas 71-72)

${ }^{3}$ Regarding the literary genre, see Flores 128. 
As the documentary Conducta impropia by Néstor Almendros and Orlando Jiménez Leal point out as well, homosexuals not only had to hide their sexual preferences but needed to repress and even deny them.

In the case of Arenas, another problem was added: his condition as a writer. Although there are several laws on freedom of opinion and expression, such as Article IV ("Right to freedom of investigation, opinion, expression and dissemination") of the American Declaration of the Rights and Duties of Man, Article 13 ("Freedom of Thought and Expression") of the American Convention on Human Rights, and even a Declaration of Principles on Freedom of Expression was adopted in 2000, it is still dangerous to publicly express criticism against the Cuban state. However, it was always a high risk as the cases of José Lezama Lima and especially Heberto Padilla show: "Lo más peligroso para el régimen era la gran cantidad de jóvenes que seguían a aquellos escritores disidentes y, por tal motivo, había que desmoralizarlos para que no se convirtieran en un símbolo; había que humillarlos y reducirlos" (Arenas 161).

Arenas, as a member of both communities, homosexuals and writers, realized the "futility" of his existence within the Cuban society when in an interview with Jacobo Machover he declared that both homosexuality and artistic creation were linked because they were both outlawed, since they did not lead to practical productions in life (266).

In addition to the human rights violations, they discriminated anyone who tried to criticize the State, but above all it targeted homosexual intellectuals because of the so called parametraje $e^{4}$. This consisted of each homosexual writer, artist and playwright receiving a telegram saying that he did not meet the political and moral standards for the position he held and was therefore left without a job or offered another one in a forced labor camp (Arenas 164). They were even arrested and imprisoned, as was the case of Reinaldo Arenas.

The human rights violations did not end there. The Principles and Best Practices on the Protection of Persons Deprived of Liberty in the Americas have been in existence since 2008. It makes explicit, among other things, the humane treatment, equality and non-discrimination and freedom of expression, association and assembly of prisoners. Even in the American Declaration of the Rights and Duties of Man of 1948 there appears an article (Article XXV) on the "Right of protection from arbitrary arrest" which states: "No person may be deprived of his liberty except in the cases and according to the procedures established by pre-existing law. [...] He also has the right to humane treatment during the time he is in custody" (17). It is not just that Reinaldo Arenas' detention was more than arbitrary. In Antes que anochezca we also realize that the treatment in El Morro prison was extremely inhumane because homosexuals occupied the underground galleys of that prison, which filled with

4 The terms "parameter" or "parameterization" can be seen as processes of establishing parameters and declaring anyone who falls outside them as "marginalized". These concepts also have been used in Cuba to discuss restrictions to public expression, especially for homosexual writers (Grenier 178-181). 
water when the tide rose (Arenas 206). Therefore, and for many other reasons, they were not treated as human beings, but as beasts.

Although most of Arena's life was spent in Cuba, his final stage of exile in the United States should not be forgotten. It is true that several human rights declarations proclaim the "Right of asylum", but emigration from Cuba, with its system of closure and surveillance, was quite difficult except during the three main migratory waves: the "Golden Exile" from 1959 to 1965, the "Freedom Flights" between 1965 and 1973 and the departure of the "Marielitos" in 1980. Unlike the first two, the last one, in which Arenas himself participated, was characterized by being much more selective. Fidel Castro did not want just anyone to become an exile either, especially when it meant a danger to the country's reputation. That's why he let leave the common delinquents and criminals, who were in the prisons, the secret agents, which he wanted to infiltrate in Miami, and the mentally ill, but not the professionals, who graduated from the university, nor the writers, with books published abroad, as was the case of Reinaldo Arenas.

However, since there was an order to let all undesirable persons go, and within that category the LGBTQ members came in first position, an immense number of homosexuals were able to leave the Island in 1980 (Arenas 299-301). In this way, and by changing a letter of his name in the handwritten passport (from Arenas to Arinas), he managed to escape.

At first, Arenas enjoyed the new freedom offered by his host country, but because of his illness, AIDS, he soon realized the vicious circle that determined his life and from which there seemed to be no way out. The scholar Beatriz Flores states in her essay "La retórica de la autobiografía en Antes que anochezca" that the autobiographer becomes a person again only in exile. His status as a homosexual is allowed without any repression. And yet, the criticism of the new system in which he lives appears shortly thereafter, sexual freedom gives way to the terror of his illness, and his life, the only thing remaining from when he left Cuba, is blurred (141) .

But this was not the only challenge Arenas had to face. His situation as a stateless writer also caused him problems. Abroad he had to endure the same attitudes and discrimination he had already suffered in his homeland. So exile, for him, meant a great disappointment as he confirms in an interview with Jacobo Machover in which he says that where he thought he would find a certain solidarity in the face of the suffering he endured on the island, he found only mistrust, hostility or incomprehension (195). In Antes que anochezca as well, he states that he was living a paradox and, at the same time, the tragic circumstances suffered by all Cuban writers throughout the ages: on the Island they were condemned to silence, ostracism, censorship and prison; in exile, to contempt and oblivion by the exiles themselves (Arenas 312).

In conclusion, it can be surmised as probable that different conditions contributed to Arenas' suicide. The reasons are probably related to the various human

\footnotetext{
${ }^{5}$ See also Hasson 170.
} 
rights violations and the areas of tension in which Arenas found himself. On the one hand, as a homosexual writer, he was trapped in Cuba as if in a prison. In his exile in the United States, he was disregarded by the other Cubans because of his rebellious behavior and his dissident texts. On the other hand, Arenas was also traumatized because he could not freely live out his sexuality, neither in Cuba nor in the United States: while he was persecuted, arrested and abused on the island because of his homosexuality, in the United States he suffered from the consequences of his AIDS illness. Finally, for many migrants of the LGBTQ community, in addition to the loss of cultural identity while facing homophobia, the factor of racism is added to the problem, making their new life in the host country even more difficult.

\section{I. WOMEN'S HUMAN RIGHTS AND THEIR VIOLATIONS}

Finally, it is appropriate to also analyze the human rights of women and the violations of those rights in El sueño de América by Esmeralda Santiago. Although the American Declaration establishes in Article II the "Right to equality before law", where every person is given the same rights "without distinction as to race, sex, language, creed or any other factor" (2), again it remains very general, even vague. More specifically, but belatedly, the Inter-American Convention on the Prevention, Punishment and Eradication of Violence against Women ("Convention of Belém do Pará") was adopted in 1994, which, in its Article 4, again highlights the rights of women like: "The right to have her life respected," "The right to have her physical, mental and moral integrity respected," or "The right to personal liberty and security" (80-81).

Despite all of the explicit rights, the conditions of women in the Americas are still often precarious, and so violations of laws are predetermined. In their countries of origin, where a patriarchal system frequently prevails, women often face social, religious, economic, physical and psychological pressures. If they aspire to free themselves from such a system, they often choose emigration as an alternative. But in making the decision to migrate, they must face new, difficult and dangerous situations, related to the process of irregular migration, such as economic extortion or sexual exploitation. And when they finally arrive in the United States, they may suffer from being uprooted and from having to abandon their families or from discrimination by the host society, as will be seen below.

\section{II. EL SUEÑO DE AMÉRICA BY ESMERALDA SANTIAGO}

Esmeralda Santiago's Elsueño de América is a classic example of the treatment of gender violence in literature. It is characterized by a high number of human rights violations and, therefore, appropriate for this study. The Belém do Pará Convention understands as violence against women "physical, sexual and psychological violence" 
(2). In the country of origin, the protagonist, América, is confronted with all three types of violence. Correa, her lover, possesses her sexually. When he has his "needs," she must satisfy them even if she does not want to (sexual violence). If she doesn't obey him, he abuses her badly (physical violence). And, on top of that, America is emotionally dependent on Correa, because he oppresses her, and she is afraid of him (psychological violence). In other words, Correa lives, in fact, on the other side of the island, has other women, children and a legal wife in Fajardo. But he always returns to América on the pretext of seeing his daughter. And when he does so, he stays in América's bed. Moreover, if any other man dares to offer América his friendship, he beats her up badly so that no one dares to enter her life for the fear that he would kill her (Santiago 27). Moreover, Correa's violent behavior is also reproduced by América, when she punishes her daughter with beatings for running away from home (Santiago 46-47), which, in turn, is an expression of the vicious circle in which the protagonist finds herself.

It should be noted that the protagonist's name does not appear coincidental. América could be seen as the embodiment of an entire continent and the abuse she experiences a metaphor for the exploitation of Latin American countries by the United States. That's what Elizabeth Coonrod Martínez confirms in her essay "Cultural Lessons by a Puerto Rican American: Esmeralda Santiago's First Novel, América's Dream":

Patriarchal control is also a metaphor for imperialistic control, just as the character América is a metaphor for a continent and a people taken by force. Correa 'participates in what he calls his pleasure, the taking of América whenever and however he wants her' (109). A mate who brutally rapes her when he is drunk, jealous, or when she is at a baby-sitting job, has no regard for her just as the "yanqui" or gringo control of the island has no regard for Puerto Rican culture and existence. $(91)^{6}$

This also becomes evident with regard to the tourists' dealings with América when they look through her and pretend not to see her, when they see her as if she were part of the strange landscape, or when they look away quickly, ashamed of having seen her (Santiago 32).

Thus, the departure from America's place of origin does not have mainly economic or political reasons but rather personal and social ones. With emigration, she tries to escape the gender-based violence Correa exerts on her and does free herself from the outdated social structures that prevail in her homeland.

Since América is Puerto Rican and therefore a citizen of the United States, crossing the border does not cause her so many legal problems. However, passing a border can also be a highly dangerous act for female migrants, as we have already seen with Beatriz in El corrido de Dante. Besides, as mentioned in the documentary Los invisibles, directed by Gael García Bernal and Marc Silver, migrant women are

\footnotetext{
${ }^{6}$ See also Domínguez Miguela 229.
} 
exposed to a high risk of sexual extortion, because an estimated 6 out of 10 women are sexually abused on their way to the United States (Los invisibles 00:08:06-00:08:12).

Once they arrive in the host country, female migrants frequently find themselves with a new division of sexual roles. Their function is not mainly limited to the domestic sphere, but they are often offered various possibilities for selfrealization. Antonia Domínguez Miguela adds in her study Pasajes de ida y vuelta: la narrativa puertorriqueña en Estados Unidos that on the island women should not go to bars where men drink and play; they should not work except at home. However, in the United States everything is different. Women are not as repressed by cultural and moral norms. Machismo is not as recalcitrant as on the island, where a single woman is the object of derision and mockery (243).

Nonetheless, it is not easy for a woman like América, who has internalized the patriarchal patterns, to free herself from the corset imposed by her society of origin. However, she too is gradually learning to enjoy her new freedoms, when she recognizes that her life is not the same she brought with her, because she has changed and evolved. For the first time in her life she's the one in control of herself and her own decisions, for example, when she's driving an almost new Volvo or when she's riding alone on a train to the city -things that would have been denied to her in her home country- (192-193).

Despite the advantages she experiences, in the United States, also there she becomes a witness to human rights violations. Article 6 on the "Right of women to be free from all forms of discrimination" (81) of the Convention of Belém do Pará, for example, is violated when Mercedes, a Latin American friend, tries to help a fallen baby girl and the girl's mother treats her in a racist way by saying to her "No la toques" ["Don't touch her"], as if she were contagious, and with a look full of mistrust and resentment. As we learn from the narrator, the same reproachful gaze follows América and her fellow employee friends wherever they go: in the shops, the assistants don't leave them alone, waiting in the hopes of catching them stealing everything they touch; on buses and trains, no one wants to sit next to them, as if sharing a seat were a too intimate association; on the street, people avoid eye contact, as if not seeing América and the other Latinas would make them disappear (Santiago 239-240), which are clearly racism based behavior patterns.

América is also confronted with discriminatory behavior in her work as a nanny. Although the host family treats her quite kindly, social differences are explicitly manifested, and a number of human rights violations occur. On the one hand, the "Right to work and to fair remuneration" (Article XIV) of the American Declaration is abused. After three months working for the Leverett family, América realizes that she is paid less than other employees. When she asks for a salary increase, she is denied, even though her boss Karen's clothes cost as much as a house in Vieques. Furthermore, in cases of emergency, they require her to stay and work during the weekend or on days off, which, moreover, violates the "Right to leisure time and to the use thereof" (Article XV) of the same declaration which states that: "Every person has the right to leisure time, to wholesome recreation, and to the opportunity for advantageous use of his free time to his spiritual, cultural and physical benefit" (15). The ultimate expression of discrepancy in the relationship between employer 
and worker is presented at the end of the novel: when Correa comes to the United States, he violently enters the Leverett house, beats América and dies in an attempt to kill her. Instead of backing her up, Karen blames América for unprofessional conduct and fires her, which in turn is evidence of the employer's ineptitude. In summary, Coonrod Martínez observes:

In her new job in New York state, América has time in the evenings to think about her life and develop a dream, but she also learns that women in a higher economic class also fail to recognize the plight of women trapped in the poverty/abuse cycle. [...] When Correa does come to New York, breaks into the house and beats América, she awakens in the hospital to find her employer there, telling América she must understand why she must fire her. Indeed, upper-class women also need to learn how to help the women who must help themselves. (90-91)

Finally, a few specific human rights violations can also be summarized for female migrants: in El sueño de América the issue of domestic violence, caused by patriarchal structures, is addressed and, once again, the topic of inhumane working conditions and racism, especially against women of color in the United States. But also the journey from Latin America to the US can pose particular dangers for women: robbery, sexual abuse (in which the young women often become pregnant) or even killing. Lastly, América barely escapes her death when Correa breaks into the Leverett's house with the intention to kill her. So, in the end, the past catches up with her and she is once again confronted with the violent abuse of her lover, although, this time, with a more positive outcome for her.

\section{CONCLUSION}

The discussion of the works by three different groups of people, often considered marginal, has allowed us to substantiate from a literary approach the different obstacles that migrants can face between Latin America and the United States. However, although Antes que anochezca is the only autobiographical novel, many of the events narrated in the three works turn out to be realities of everyday inter-American life and, thus, also a reflection of the current situation in the Americas.

The abovementioned analysis has helped to provide testimony that human rights violations can be addressed from multiple points of view. El sueño de América, for example, criticizes gender-based violence that abuses the right to respect life, physical, psychological and moral integrity and personal safety (Article 4 of the $C B P$ ). The novel furthermore addresses the violation of the "Right of women to be free from all forms of discrimination" (Article 6 of $C B P$ ) in the social and labor fields. In Antes que anochezca, the "Right to equal protection against any form of discrimination and intolerance" (Article 2 of the $I C D I$ ), the "Right to freedom of investigation, opinion, expression and dissemination" (Article IV of the ADRDM) and the "Right of protection from arbitrary arrest" (Article XXV of the ADRDM), 
among others, are violated. Finally, in El corrido de Dante, rights such as free "Movement" and "Residence" (Article 22 of the $A C H R$ ) and "Just, Equitable, and Satisfactory Conditions of Work" (Article 7 of the "Protocol of San Salvador") are infringed. Despite the different forms of expression, for which each of the works analyzed stands out, there is a common thread running through all three novels: the denunciation of human rights violations.

This study has concentrated on a relation, confrontation, or setting in perspective of three types of references on the subject in question: the existing legislation, what happens in reality, and the contribution or position of literature. We have seen that, on the one hand, there is a huge gap between legislation and reality. On the other hand, we have literature that often expresses reality in a much more authentic way than the existing laws, despite, or thanks to, the recourse to fiction. In this regard, the US Latino or, more generally, inter-American narratives serve as tools for raising the reader's awareness of the human rights violations that occur in the Americas and, in the ideal case, for leading to concrete action. The mere existence of human rights is not enough to prevent their violation. There is a need for social participation in high-risk places. Literature, in this instance, can have the function of an impulse, of a first step towards the improvement of the situation, but it does not give us definitive answers or ideal solutions. It is up to each individual to look for possible procedures to change the situation and improve it.

REVIEWS SENT TO AUTHOR: 15-7-2020; REVISED PAPER ACCEPTED FOR PUBLICATION: 15-9-2020 


\section{WORKS CITED}

Arenas, Reinaldo. Antes que anochezca. Tusquets, 1992.

Butler, Judith. "La lucha debe ser por una vida vivible.” Revista N (24 July 2010) http://edant. revistaenie.clarin.com/notas/2010/07/24/_-02205790.htm. Accessed 16 June 2020.

Coonrod Martínez, Elizabeth. "Cultural Lessons by a Puerto Rican American: Esmeralda Santiago's First Novel, América’s Dream.” Bilingual Review/La Revista Bilingüe 23/1 (1998): $88-92$.

Domínguez Miguela, Antonia. Pasajes de ida y vuelta: la narrativa puertorriqueña en Estados Unidos. Universidad de Huelva, 2005.

Flores, Beatriz. "La retórica de la autobiografía en Antes que anochezca." Del alba al anochecer: la escritura en Reinaldo Arenas. Ed. María Teresa Miaja. Iberoamericana/Vervuert, 2008. 127-143.

García, Audrey E. "Mexican Immigration and Popular Culture in El corrido de Dante by Eduardo González Viana." (Re)Collecting the Past: History and Collective Memory in Latin American Narrative, ed. Victoria Carpenter. Peter Lang, 2010. 217-239.

GonZález Viaña, Eduardo. El corrido de Dante. Alfaqueque, 2008.

Grenier, Yvon. "The Politics of Culture in Cuba." Handbook of Contemporary Cuba: Economy, Politics, Civil Society and Globalization 1. Eds. Mauricio Font \& Carlos Riobó. Paradigm Press, 2013. 173-190.

Hasson, Liliane. "«Antes que anochezca (Autobiografía)»: una lectura distinta de la obra de Reinaldo Arenas." La escritura de la memoria. Ed. Ottmar Ette. Iberoamericana/Vervuert, 1996. 165-173.

IMOBERDORF, Sebastian. "Volver a las raíces: la búsqueda de identidad en la narrativa interamericana." Volver: culturas e imaginarios del retorno a y desde América Latina. Eds. Adriana LópezLabourdette, Valeria Wagner \& Daniel Bengsch. Linkgua, 2018. 101-124.

MaCHOVER, Jacobo. La memoria frente al poder: escritores cubanos del exilio, Guillermo Cabrera Infante, Severo Sarduy, Reinaldo Arenas. Universidad de Valencia, 2001.

Manzano Franco, Javier. "El Corrido de Dante de Eduardo González Viaña y la irrupción de lo mítico en la novela de la inmigración.” Activarte: Revista Independiente de Arte, Teoría de las Artes, Pedagogía, Nuevas Tecnologías 2 (2009): 41-46.

Olsson, Fredrik. "Ballads without Borders. Transnational Identities and Voices of Latino/a Migrant Experiences in El Corrido de Dante by Eduardo González Viaña." American Studies in Scandinavia 43/1 (2011): 55-72.

Reyes-ZAGA, Héctor A. "Teatro y derechos humanos: representaciones de la experiencia migratoria mexicana en Los ilegales y El viaje de los cantores." A Contracorriente 13/2 (2016): 121-148.

Santiago, Esmeralda. El sueño de América. Harper Collins, 1996.

Santiago, Esmeralda. América's Dream. Harper Collins, 1996.

TARrow, Sidney. El poder en movimiento: los movimientos sociales, la acción colectiva y la política. Alianza, 1998. 


\section{LegisLATIVE DOCUMENTS}

Advisory Opinion OC-18/03. 2003. Inter-American Court of Human Rights, https://www.corteidh. or.cr/docs/opiniones/seriea_18_ing.pdf. Accessed 16 June 2020 .

American Convention on Human Rights. 1969. Organization of American States, http://www.oas.org/ dil/treaties_B-32_American_Convention_on_Human_Rights.pdf. Accessed 16 June 2020.

American Declaration of the Rights and Duties of Man. 1948. Organization of American States, http:// www.oas.org/en/iachr/mandate/Basics/american-declaration-rights-duties-of-man.pdf. Accessed 16 June 2020.

"Convention of Belém do Pará": Inter-American Convention on the Prevention, Punishment and Eradication of Violence against Women, 1994. Organization of American States, http:// www.oas.org/en/iachr/mandate/Basics/inter-american-convention-violence-womenbel\%C3\%A9m-do-par\%C3\%A1.pdf. Accessed 16 June 2020.

Declaration of Principles on Freedom of Expression. 2000. Organization of American States, http:// www.oas.org/en/iachr/mandate/Basics/declaration-principles-freedom-expression.pdf. Accessed 16 June 2020.

Inter-American Convention Against All Forms of Discrimination and Intolerance. 2013. Organization of American States, http://www.oas.org/en/sla/dil/docs/inter_american_treaties_A-69_ discrimination_intolerance.pdf. Accessed 16 June 2020.

Principles and Best Practices on the Protection of Persons Deprived of Liberty in the Americas. 2008. Organization of American States, http://www.oas.org/en/iachr/mandate/Basics/principlesbest-practices-protection-persons-deprived-liberty-americas.pdf. Accessed 16 June 2020.

"Protocol of San Salvador": Additional Protocol to the American Convention on Human Rights in the Area of Economic, Social and Cultural Rights. 1988. Organization of American States, http:// www.oas.org/en/iachr/mandate/Basics/protocol-San-Salvador-economic-social-culturalrights.pdf. Accessed 16 June 2020.

Universal Declaration of Human Rights. 1948. United Nations, https://www.ohchr.org/EN/UDHR/ Documents/UDHR_Translations/eng.pdf. Accessed 16 June 2020.

\section{Movies}

Conducta impropia. Dir. Néstor Almendros \& Orlando Jiménez Leal. Starred Reinaldo Arenas. Les films du Losange, 1984.

Los invisibles. Dir. Gael García Bernal \& Marc Silver. Starred Gael García Bernal. Canana Films, 2010. 